\title{
Diallel Analysis of Five Tomato Cultivars and Estimation of Some Genetic Parameters for Growth and Yield Characters
}

\author{
Solieman, T.H.I. ${ }^{1}$
}

\begin{abstract}
Five commercial tomato (Lycopersicon esculentum, Mill) cultivars and their ten $F_{1}$ hybrids, in a diallel cross system without reciprocals, were used in this study to detect the general performance, and to estimate heterosis percentages relative to mid parents, potence ratios, general -and specific- combining ability, and heritability percentages in broad and narrow senses for some important characters.
\end{abstract}

The obtained results reflected generally that the used parental cultivars appeared to have wide ranges of variabilities in the various studied characters and their detected differences were found significant in the most cases . The general performances of the $F_{1}$ hybrids of some characters reflected the presence of partial-to overdominance, but with different magnitudes. On the other hand, some other studied characters suggested the presence of partial-to under-recessiveness with different degrees. Positive and desirable heterotic effects were reflected on the performances of most of $F_{1}$ hybrids for certain characters. On the contrary, negative heterotic effects (undesirable) were also detected on some $F_{1}$ hybrids for some other characters. The obtained results reflected also that both additive and non-additive gene effects contributed ,with different degrees, to the basic genetic mechanisms involved in the inheritance of all studied characters. However, the non-additive gene effects seemed to be relatively more important than those of the additive effects. These results were also confirmed by the high estimates of $\sigma^{2}$ sca relative to those of $\sigma_{\text {gca }}^{2}$, the estimated values of potence ratios, and the estimates of both broad-and narrow-sense heritability.

The results indicated also that a particular cultivar or hybrid can not be used to evaluate all studied characters with equal efficiency. However, the best general combiner parent that appeared to have the significant highest positive value of G.C.A. was found to be cultivar "Super Marmand" (for the characters plant height ,number of branches per plant and total soluble solids), cultivar "Peto-86" (for the characters plant height to the first flower, number of flowers per cluster, number of fruits per plant and fruit shape index), cultivar "Edkawy" (for the characters fruit weight ,fruit diameter ,fruit length and fruit locules number), and cultivar "Super Strain-B" (for the character total fruits weight per plant).

The results indicated also that the best hybrid combinations were $C \times M$ (for the plant heigh), $S \times E$ (for the four characters number of branches per plant, plant height to the first flower, number of fruits per plant ,and total fruits weight per plant), $\mathbf{C} \times \mathbf{P}$ (for the characters number of flowers per cluster and fruit shape index), $M \mathbf{x}$ $E$ (for fruit weight), $S \times M$ ( for the fruit length character) , $\mathbf{P} \times \mathbf{S}$ ( for fruit diameter and number of locules per fruit characters), and the cross $P \times M$ (for total soluble solids).

\section{INTRODUCTION}

Tomato (Lycopersicon esculentum, Mill; $2 \mathrm{n}=24$ ) is one of the most important and popular vegetable crops in Egypt as well as in most of countries around the world. As a cash crop, it has a great demand in the international market (Hannan et al., 2007a).In recent years, tomato growers used to grow hybrid cultivars, in spite of the relatively high prices of their seeds, in order to maximize the net return of their investments; since, the hybrids are usually characterized by high yield and good quality with high homogeneity, compared with the open-pollinated cultivars. Accordingly, tomato breeders directed their attention in their programs to keep introducing new hybrids to suffice the increased and changeable demands of both growers and consumers.

Heterosis, or hybrid vigor, is defined as the ability of hybrids to outperform their best inbred parent with respect to growth, yield and other quantitative traits (Semel et al., 2006).Heterosis is a biological phenomenon manifesting itself in hybrids that are more vital, adaptive and productive than their parents. Heterosis has been explained by over-dominance and by additive effects (Bai and Lindhout,2007). However, it is still unclear how much each of these effects contributes to the total heterosis effect (Semel et al., 2006). Also, it is an important tool that can facilitate yield enhancement from $30 \%$ to $400 \%$ and help enrich many other desirable quantitative and qualitative traits in crops. Heterosis in the $F_{1}$ hybrids of tomato was reported by many researchers such as KhalfAllah(1971); Ahmed et al.,(1988); Omara et al., (1988); Suresh et al., (1995); Gad-El-Hak et al., (1996); Ajeet et al., (1996); Srivastava et al., (1998); Kurian et al., (2001);Kurian and Peter (2001);Pratta and Picardi (2003);Semel et al., (2006); Pradheep et al., (2006);Bai and Lindhout (2007); Hannan et al., (2007a).From their

\footnotetext{
${ }^{1}$ Vegetable Crops Department, Faculty of Agriculture,

Alexandria University, Alex,Egypt.

Received June21, 2009, Accepted June29, 2009
} 
studies, clear heterotic effects were observed on some important tomato traits.

Information on the relative importance of general combining ability (G.C.A.) and specific combining Ability (S.C.A) are of great values in the breeding programs for the species which are amenable to the development of $F_{1}$ hybrid cultivars, as tomato. In general, when a particular line reflects a high estimate of G.C.A. it means that it is a good combiner parent and possesses good genes; whereas, a high S.C.A. of a particular combination means that the parents of this cross can combine well to produce a hybrid with a superior general performance, which reflects a clear heterotic effect. Moreover, when the additive gene action represents the major component of the total genetic variation; G.C.A. parameter would be high and a maximum progress would be expected in a selection program; while, a hybrid breeding program may be the appropriate choice if the non-additive gene action is the major component, as reflected with S.C.A. estimate (Cockerham, 1961).The diallel analysis system is suitable for this purpose, since it is usually conducted to estimate various and important genetic parameters, such as additive and non-additive variances, heritability percentages $\left(\mathrm{H}^{2}{ }_{\text {bs }}\right.$ and $\left.\mathrm{h}^{2}{ }_{\mathrm{ns}}\right)$, and general and specific combining ability (G.C.A. and S.C.A.) of the lines and crosses, respectively. Several investigators used a diallel crossing system in studying the inheritance of some quantitative characters in tomato for estimating different genetic parameters, such as general and specific combining ability (Omara et al., 1988; Younis et al., 1988; Ghosh et al.,1996;Kurian and Peter, 1997; Srivastava et al., 1998; Abd-Allah,1999;WahbAllah,2000;Pratta and Picardi.,2003; Geleta et al., 2006;Pradheep et al., 2006; and Hannan et al., 2007b) .

Heritability in broad and/or narrow sense percentages of some important tomato traits were estimated by many researchers such as Khalil et al., (1988);Omara et al.,(1988);Singh et al., (1988); AbdelAti (1999);Prasad and Rai (1999);WahbAllah(2000); Pradeepkumar et al., (2001) ; Hanson et al., (2002); and Singh and Cheema (2005).

Accordingly, the present investigation was suggested to try and to introduce some good tomato hybrids through the evaluation of the general performances of five cultivars and their all possible hybrid combinations in one direction. Estimates of some important genetic parameters; general combining ability (G.C.A.) and specific combining ability (S.C.A.), heterosis relative to mid parents ,potence ratio, and heritability percentages in both broad and narrow senses, were estimated for some important characters.

\section{MATERIAL AND METHODS}

This study was carried out in three seasons during the years of 2006,2007 and 2008, at the Experimental Station Farm of the Faculty of Agriculture (at Abies), Alexandria University, Alex., Egypt.

In the first and the second seasons, the parental tomato cultivars were grown in a greenhouse to conduct all needed crosses and selfing; while in the third season, tomato plants were grown in the open - field for the evaluation trial.

\section{Growing and Selfing of the Parental Cultivars (First season):}

Five commercial tomato cultivars, differing in several characters, were chosen as the original plant materials and grown to obtain their true-selfed seeds. These tomato cultivars were "CastelRock" (C), Peto86(P), 'SuperStrain-B "(S)," SuperMarmand" (M), and "Edkawy" (E).Seeds of the five tomato parental cultivars were sown in pots (30 $\mathrm{cm}$ in diameter) filled with a soil mixture (of equal parts of sand, clay and silt) at the rate of 20 seeds per pot, in a greenhouse, on December 25, 2006; using two pots for each cultivar. Seedlings were transplanted in pots filled with the above mentioned soil mixture on February 8, 2007; and each cultivar was represented by seven pots. All cultural practices; such as fertilization, irrigation, and plant protection against weeds, diseases and insects, were performed whenever it was thought necessary. At the flowering stage, selfing of the five parental cultivars were conducted to obtain their true-selfed seeds. Four clusters per plant were used and two flowers per cluster were chosen to develop into a mature fruit; whereas, the other flowers were thinned out. At the beginning till the end of May, 2007,fruits of each cultivar were harvested at the suitable ripening stage. Their seeds were extracted by hand maceration, washed, cleaned and air dried to be used in a crossing program to develop the required genetic material.

\section{Development of Genetic Material (Second Season)}

This work was conducted in a greenhouse. The previously obtained selfed seeds of the parental cultivars were sown on October 28,2007 in pots $(30$ $\mathrm{cm}$ in diameter) filled with a soil mixture consisting of equal parts of sand, clay and silt .Seedlings were transplanted in pots $(30 \mathrm{~cm}$ in diameter), filled with the above mentioned soil mixture, on December 12,2007.Each cultivar was represented by ten pots, and all needed cultural practices were performed. Then, hybridization and selfing among the five parental cultivars were carried out, using a diallel cross system in one direction at the proper stage of flower-bud development, which was 1-2 days before anthesis, to obtain enough seeds of all possible 10 hybrids and new selfed seeds of the five parental cultivars. A set of 
seven plants was used to provide the hybrid $F_{1}$ 's seeds for each particular cross. Four clusters per plant were used and only one flower per cluster was chosen to develop into a mature fruit; whereas, all other flowers were thinned out. Crossing among the parental cultivars was carried out according to a guide schedule and lasted from the beginning of February till the middle of March, 2008. By the end of April , 2008, enough seeds were obtained for each of the 10 different $F_{1}$ hybrids and the five selfed parental cultivars.

\section{Evaluation of the Genetic Populations (Third Season)}

Seeds of the fifteen different genetic populations ( 5 parents and $10 \mathrm{~F}_{1}$ hybrids) were sown in pots $(30 \mathrm{~cm}$ in diameter), filled with the previously mentioned soil mixture, at the rate of 25 seeds per pot, on June 5,2008. Six pots were used for each genotypic population. Seedlings were transplanted into open field on July 10, 2008. The used experimental design was randomized complete blocks (R.C.B.D.), with three replicates. In each replicate, each of the 15 populations was represented by a plot of 36 plants in three rows. The row was four meters long and $1.20 \mathrm{~m}$ wide, with a spacing of $0.35 \mathrm{~m}$ between the growing plants. Common fertilization, irrigation, plant protection against weeds, diseases and insects; were performed whenever they were thought necessary and as recommended for commercial tomato production.

\section{Experimental Data}

All the experimental data were measured on individual plant basis. At $50 \%$ blooming stage, the vegetative growth characters; that included plant height (cm), number of branches per plant and plant height to the first flower; and the character number of flowers per cluster were measured for each plant. Samples of five random ripe fruits per plant were taken to measure the fruit characteristics; i.e., fruit diameter $(\mathrm{cm})$, fruit length $(\mathrm{cm})$, fruit shape index (as a ratio between length and diameter of fruit ,L/D), number of locules per fruit, and total soluble solids (T.S.S.\%) of tomato juice, using a hand refractometer. All harvested fruits of each plant were counted and weighed to determine number of fruits per plant and total fruits weight per plant, respectively. Average fruit weight was also estimated by dividing the total weight of all harvested fruits per plant on their total number.

\section{Statistical Analyses and Estimation of Genetic} Parameters

Data of all the studied characters were arranged and statistically analyzed, using the standard methods of the randomized complete blocks design. The differences among the various means were tested, using Duncan's multiple range test (L.S.R), as illustrated by Al-Rawi and Khalf - Allah (1980), using Co-State Software (2004), computer program. Also, the values of general combining ability (G.C.A.) and specific combining ability (S.C.A.) effects were estimated, according to Griffing (1956a,1956b); model two of method two, which depends on parental cultivars and their $F_{1}$ 's in one direction. The used model is illustrated by the analysis of variance presented in Table 1, as follows:

From the (E.M.S) given in Table 1, the estimations of variance components of G.C.A. $\left(\mathrm{O}_{\mathrm{gca}}^{2}\right)$ and S.C.A. $\left(\mathrm{O}_{\text {sca }}^{2}\right)$ were calculated as:

$\mathrm{O}_{\mathrm{gca}}^{2}=1 / \mathrm{n}+2\left(\mathrm{M}_{\mathrm{g}}-\mathrm{M}_{\mathrm{e}}\right)$

$\mathrm{O}_{\mathrm{sca}}^{2}=\mathrm{M}_{\mathrm{s}}-\mathrm{M}_{\mathrm{e}}$

Estimation of G.C.A. effects, $\mathrm{G}_{\mathrm{i}}$, were defined as follows:

$G_{i}=1 / n+2-\left[\Sigma\left(Y_{i .}+Y_{i i}\right)-2 / n Y ..\right]$

Estimation of S.C.A. effects, $\mathrm{S}_{\mathrm{ij}}$, were defined as follows:

$S_{i j}=Y_{i j}-1 / n+2\left(Y_{i}+Y_{i i}+Y_{\cdot j}+Y_{i j}\right)+2 /(n+1)(n+2) Y_{. \cdot}$

The stander error (S.E.) of the estimated general and specific combining abilities effects were obtained as follows:

$$
\begin{aligned}
& \text { S.E. }\left(G_{j j}-G_{j}\right)=\left[2 O^{2}{ }_{e} /(n+2)\right]^{1 / 2} \\
& \text { S.E. }\left(S_{j j}-S_{j k}\right)=\left[2(n+1) O^{2}{ }_{e} /(n+2)\right]^{1 / 2} \\
& \text { S.E. }\left(S_{j j}-S_{k l}\right)=\left[2 n O^{2}{ }_{e} /(n+2)\right]^{1 / 2} \\
& \text { where: }
\end{aligned}
$$

$G_{i}-G_{j}$ : difference between two G.C.A. estimates of two parental cultivars.

$S_{i j}-S_{i k}$ : difference between two S.C.A. estimate of two hybrids, with a common parent.

$S_{\mathrm{ij}}-S_{\mathrm{kl}}$ : difference between two S.C.A. estimate of two hybrids with non-common parent.

Table 1. Analysis of variance for the estimation of (G.C.A) and (S.C.A) components

\begin{tabular}{llccc}
$\begin{array}{l}\text { Sources of } \\
\text { variation } \\
\text { (S.C.V) }\end{array}$ & Degree of freedom & Sum of squares & Mean squares & Expected mean square \\
\hline G.C.A & (D.F.) & (S.S.) & (M.S.) & \multicolumn{1}{c}{ (E.M.S) } \\
S.C.A & $\mathrm{n}(\mathrm{n}-1) / 2=10$ & $\mathrm{~S}_{\mathrm{g}}$ & $\mathrm{M}_{\mathrm{g}}$ & $\mathrm{Oe}^{2}+\mathrm{O}^{2}(\mathrm{n}+2) \mathrm{O}_{\text {gca }}^{2}$ \\
Error & $(\mathrm{r}-1)(\mathrm{p}-1)=28$ & $\mathrm{~S}_{\mathrm{s}}$ & $\mathrm{M}_{\mathrm{s}}$ & $\mathrm{Oe}^{2}+\mathrm{O}^{2}{ }_{\text {sca }}$ \\
\hline
\end{tabular}


Heritability in both broad $\left(\mathrm{H}^{2}{ }_{\mathrm{bs}}\right)$ and narrow $\left(\mathrm{h}^{2}{ }_{\mathrm{ns}}\right)$ senses were calculated according to Gibrel et al., (1982), using the following formula:

$\mathbf{H}^{2}{ }_{\mathrm{bs}}=\left(2 \mathrm{O}_{\mathrm{g}}^{2}+\mathbf{O}_{\mathrm{s}}^{2}\right) /\left(2 \mathrm{O}_{\mathrm{g}}^{2}+\mathrm{O}_{\mathrm{s}}^{2}+\mathrm{O}_{\mathrm{e}}^{2}\right)$. $\mathbf{h}^{2}{ }_{\mathrm{ns}}=\left(2 \mathrm{O}_{\mathrm{g}}^{2}\right) /\left(2 \mathrm{O}_{\mathrm{g}}^{2}+\mathrm{O}_{\mathrm{s}}^{2}+\mathrm{O}_{\mathrm{e}}^{2}\right)$.

Heterosis percentages, relative to the mid parents values, for the different studied characters were estimated, using the formula of Mather and Jinks(1971)as follows:

Helterosis \% relative to mid parents $=\overline{F_{1}-\overline{M P}}$

\section{MP}

Where: $\overline{\mathbf{F}}_{1}$ is the mean of the $\overline{F_{1}}$ population, , and MP is the mean of the two parental value.

Potence ratio was calculated according to Smith (1952) to determine the degree of dominance as:-

$$
\begin{aligned}
& \bar{F}_{1}-\overline{M P} \\
& \left.\mathbf{P}=\text { - } 0.5 \overline{(\mathbf{P}}_{2}-\overline{\mathbf{P}}_{1}\right)
\end{aligned}
$$

Where:

\section{P: relative potence of gene set. \\ $\underline{F_{1}}$ : first generation mean. \\ $\underline{P_{1}}$ : the mean of lower parent. \\ $\underline{P_{2}}$ : the mean of higher parent.

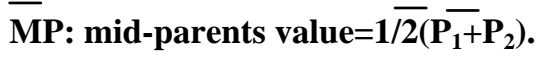 \\ Where:}

Complete dominance is indicated when" $P$ "= +1.0; while partial dominance is indicated when " $P$ " is between (-1 and +1); except the value zero, which indicates absence of dominance. Over-dominance is considered when potence ratio exceeds +1 .The positive and negative signs indicate the direction of dominance of either parents.

\section{RESULTS AND DISCUSSION}

\section{General Performance of the Evaluated Genetic Populations}

The results of the comparisons among the mean performances of the 15 tested genetic populations for the various studied characters of tomato are presented in Table 2.Generally, the results of the mean values of the parental cultivars for the studied characters showed relatively wide ranges of genetic variabilities among the parental cultivars for most studied traits. The differences among the means of the parental cultivars in most studied characters appeared to be significant. The parental cultivar "Super Marmand" (S) gave the highest mean values for the characters plant height and number of flowers per cluster. On the other side, the two cultivars "Peto-86"(P) and "Castel Rock" (C) reflected the lowest mean values for the two mentioned characters, respectively. Concerning the number of branches per plant and plant height to the first flower, the highest mean values were reflected by the parental cultivar "Peto-86" (P); while, the parents "Super StrainB"(S) and "Castel Rock" (C) gave the lowest mean values for these two characters. Such results are in general agreements with the findings of WahbAllah(2000) for the characters number of branches per plant, plant height to the first flower and number of flowers per cluster, since the differences among the mean performances of most parental cultivars appeared to be significant for these characters. The result concerning plant height character, in the present study, is in agreement with the finding of Pradeepkumar et al., (2001), who found significant differences among the genotypes of tomato for plant height character. The comparisons among the $F_{1}$ hybrids mean values of the four characters ;i.e, plant height ,number of branches per plant, plant height to the first flower and number of flowers per cluster (Table 2)demonstrated generally that all of the first hybrid generations tended to be either higher than their respective lower parent or deviated towards the higher parent ;but, with few exceptions. Similar results were reported by Wahb-Allah (2000)for number of branches per plant ,number of flowers per cluster and plant height to the first flower; by Hannan $e t$ al., (2007a) for number of flowers per cluster, and by Pradeepkumar et al., (2001)for plant height. These authors found generally that both additive and nonadditive gene effects were involved in the inheritance of these characters; but, additive gene effects played more important role than non-additive effects. The highest values of the characters plant height and number of branches per plant of all $\mathrm{F}_{1}$ hybrids were given by the $\mathrm{F}_{1}$ hybrid $\mathrm{C} \times \mathrm{M}$, followed by the $\mathrm{F}_{1}$ of the cross $\mathrm{M} \times$ $\mathrm{E}$; whereas, the lowest values were given by the two $F_{1}$ hybrids $\mathrm{P} \times \mathrm{E}$ and $\mathrm{C} \times \mathrm{S}$ for the two traits, respectively. Concerning the two characters plant height to the first flower and number of flowers per cluster, the highest mean values were shown by the $F_{1}$ hybrids $\mathrm{P} \times \mathrm{E}$ and $\mathrm{C}$ $\times \mathrm{P}$, respectively. Such high performances of the mentioned $F_{1}$ hybrid populations could be related to the types of gene action involved on the inheritance of these 
characters, that reflected some importance for the roles of additive and non- additive gene effects, but with different magnitudes.

The results concerning the comparisons among the general performances of the parental cultivars for the characters number of fruits per plant and total fruits weight per plant illustrated that the parental cultivars "Peto-86" and "CastelRock" reflected the highest 



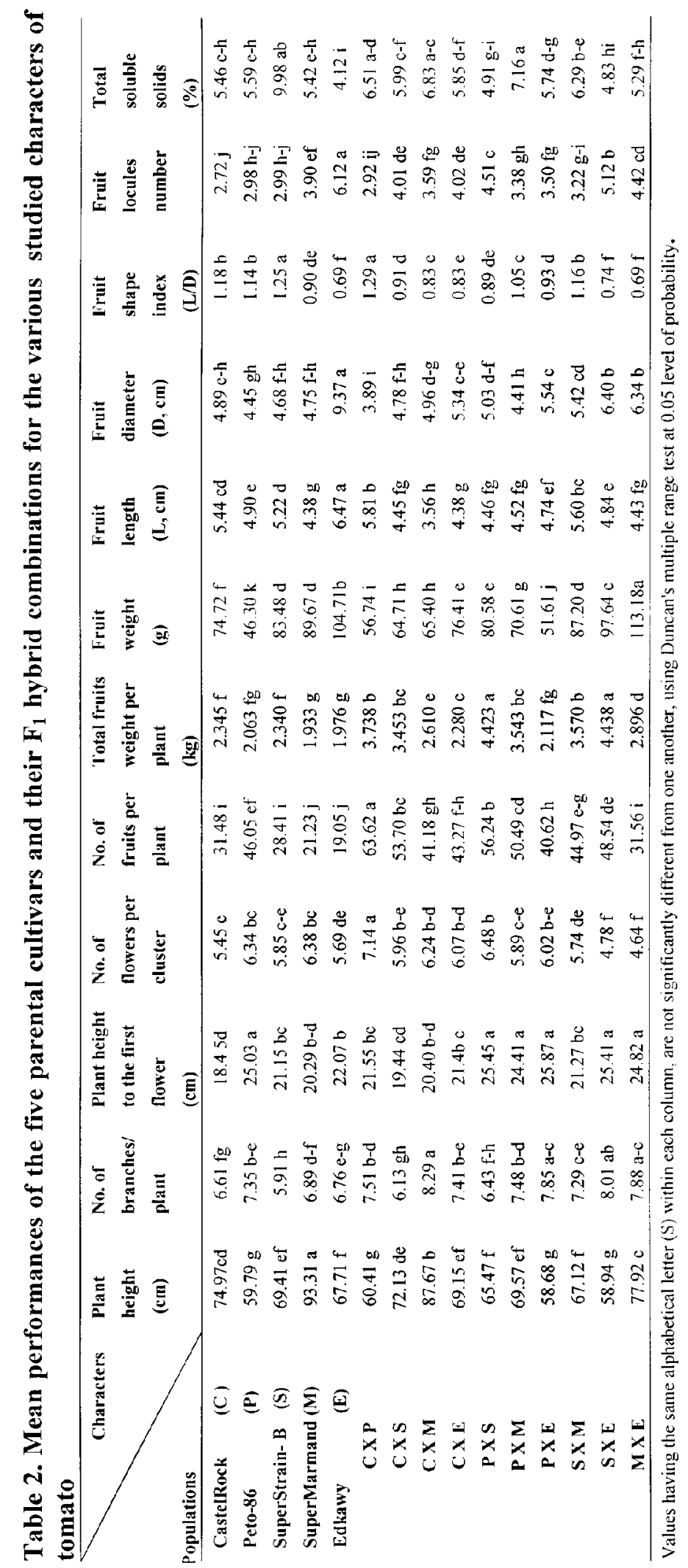


mean values for these two characters, respectively. On the contrary, the cultivar "Edkawy" for the number of fruits per plant and the cultivar "Super Marmand" for total fruits weight per plant reflected the lowest mean values among all the parental cultivars. This result seemed to agree with the finding of Pradeepkumar et al., (2001) ,who found significant differences among parental genotypes for the characters number of fruits per plant and fruits yield per plant. In the same trend, Wahb -Allah (2000) reported similar results concerning the differences among parental cultivars of tomato for the number of fruits per plant and total fruits weight per plant characters.

The results in Table 2 showed generally that all $F_{1}$ hybrids populations produced averages that tended to be either more than their respective mid-or betterparental values for number of fruits per plant and total fruits weight per plant. Such results suggested that the $F_{1}$ hybrid generations reflected general superiority on their number of fruits per plant and total fruits weight per plant, which could be generally expected on the basis of hybrid vigor expression, predominantly contributed by the non-additive gene effects. Among the ten $F_{1}$ hybrids, the highest mean values were found to be those of the $\mathrm{F}_{1}$ hybrid $\mathrm{C} \times \mathrm{P}$, followed by the $\mathrm{F}_{1}$ of the cross $\mathrm{P} \times \mathrm{S}$ for number of fruits per plant, and the hybrid $\mathrm{S} \times \mathrm{E}$, followed by the $\mathrm{F}_{1}$ of the cross $\mathrm{P} \times \mathrm{S}$ for the total fruits weight per plant. These results indicated generally that both additive and non-additive gene action were involved in the genetic mechanism controlling the inheritance of number of fruits per plant and total fruits weight per plant. Moreover, the results illustrated that non-additive gene effects were more pronounced in the basic mechanism, controlling the inheritance of these characters, relative to the additive gene effects. The present results are in agreement completely with those reported by Khalf -Allah and Mousa (1972); Khalf Allah and Kassem (1985); Wahb -Allah (2000); Hannan et al.,(2007b). Meanwhile, Omara et al., (1988) found that additive variance was consistently greater than the non-additive variation, indicating that the major portion of the genetic variation for the characters number of fruits per plant and total fruits yield per plant was controlled by genes with additive effects.

Regarding the characters fruit weight, fruit length, fruit diameter and fruit locules number, the parental cultivar "Edkawy" gave the highest mean values for the mentioned characters, with significant differences, comparing with those of all other parental cultivars (Table2). On the other side, the parental cultivar "Super Strain- B" gave the highest mean values for fruit shape index and total soluble solids characters. Such results reflected a general agreement with those obtained by Wahb-Allah (2000)for fruit shape index ,fruit weight and total soluble solids; Srivastava et al., (1998) and Pradeepkumar et al., (2001) for fruit length, fruit diameter, number of locules per fruit, and fruit weight. The comparisons among the general performances of the $F_{1}$ hybrids illustrates that the $F_{1}$ hybrid $M \times E$ displayed the highest value for fruit weight; the $F_{1}$ hybrid $\mathrm{C} \times \mathrm{P}$ gave the highest mean values for fruit length and fruit shape index; the $\mathrm{F}_{1}$ hybrid $\mathrm{S} \times \mathrm{E}$ was the highest for fruit diameter and fruit locules number per fruit. Whereas, the $\mathrm{F}_{1}$ of the cross $\mathrm{P} \times \mathrm{M}$ gave the highest mean value for the total soluble solids character However, the results of the general performances of the various populations reflected hybrid vigor. The $F_{1}$ hybrids within the different 15 populations suggested that various degrees of dominance and over-dominance were involved in the inheritance of these characters. The results illustrated also that the non-additive gene effects seemed to be more pronounced in the basic genetic mechanism, controlling the inheritance of these characters relative to the additive effects. The present results are in agreement with those reported by Geleta et al., (2006)and Hannan et al., (2007b) for fruit weight, fruits yield per plant and T.S.S content .

\section{Heterosis and Potence Ratio Estimates of the $F_{1}$ hybrid Generations:}

The estimated values of heterosis percentages, relative to mid parental values of the $F_{1}$ hybrids, and potence ratios of the ten $F_{1}$ hybrid populations on the different studied characters are listed in Tables 3 and 4.

The estimates of heterosis, relative to mid parental values reflected desirable heterotic effects, with positive signs, on two, three and four $F_{1}$ hybrids for the characters plant height and fruit length, fruit diameter and fruit shape index, respectively. Likewise, the estimated potence ratios reflected generally the presence of partial and over-dominance for the higher values of the above mentioned characters over those of the lower ones. Such results are in a harmony with the findings of Srivastava et al., (1998) for the characters plant length, fruit length and wide; and Kurian et al., (2001) for fruit shape index. They noticed that most of the first generation hybrids were higher and more vigorous than their parental cultivars, indicating that high heterotic effects supported the role of non-additive gene effects for these characters. The other $F_{1}$ hybrid populations reflected negative and undesirable heterotic effects for these mentioned characters. This result indicated the presence of the various degree of recessiveness; i.e., partial-to under-recessiveness, which seemed to be involved in the inheritance of these 
characters in particular populations. This result was

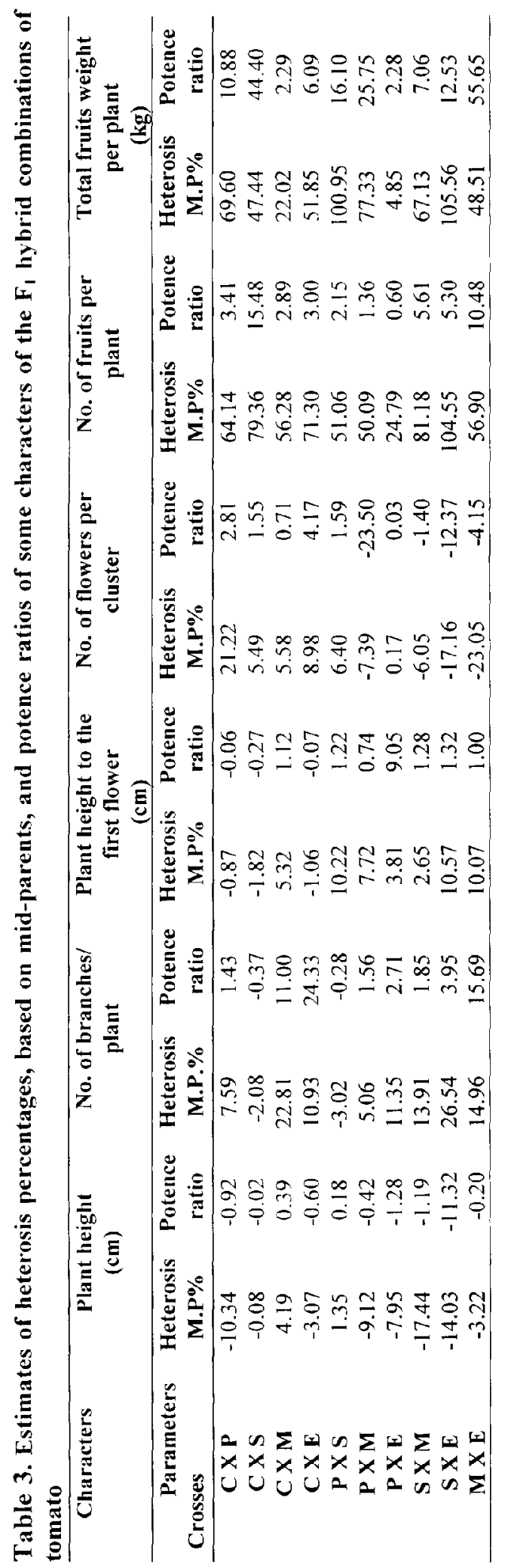

also confirmed by the potence ratios, which appeared to

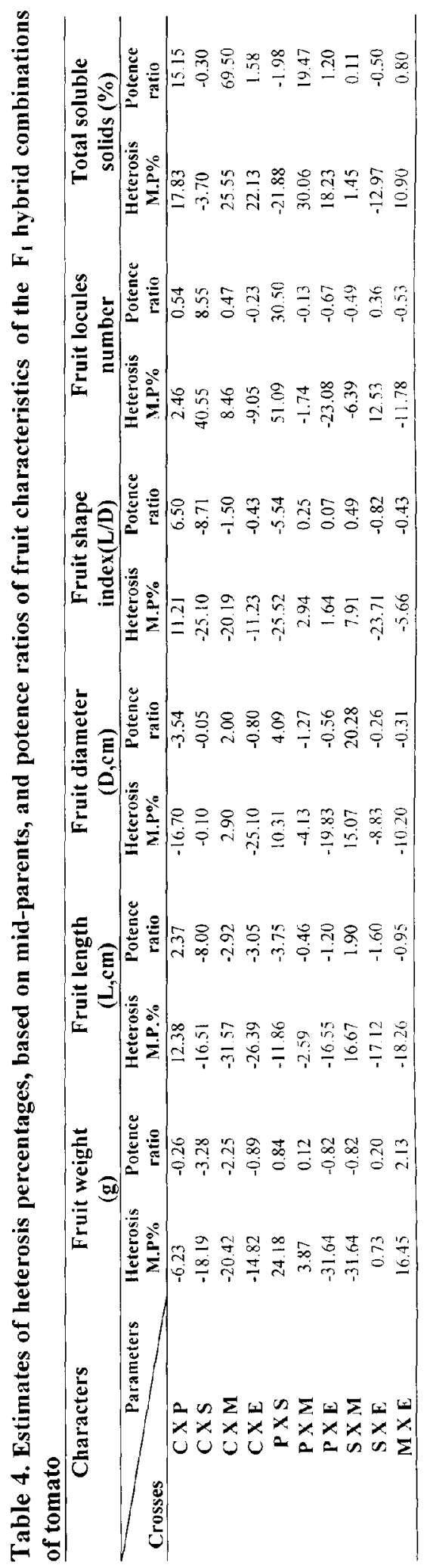


have negative values for the most of these $\mathrm{F}_{1}$ 's ,indicating the presence of partial - to under recessiveness effects.

The results given in Table 4 indicated generally that desirable and positive heterotic effects were reflected on half of the $F_{1}$ hybrids for the fruit weight and number of locules per fruit. This result was also confirmed by potence ratios, which appeared to have positive values for five $F_{1}$ hybrids, indicating the presence of partial -to over- dominance effects. These results were found to agree with those reported by many researchers such as Srivastava et al.,(1998), Hazar et al., (2001)and Kurian et al., (2001) for locules number per fruit; and Kurian et al.,(2001) and Pradheep et al., (2006)for fruit weight. They reported that the estimated heterosis values reflected positive effects, suggesting that dominance and over - dominance effects played important roles in the inheritance of these characters. On the other hand ,the other half of the $F_{1}$ hybrids for the characters fruit weight and number of locules per fruit reflected negative heterotic effects (undesirable), which were supported by the potence ratios with negative signs. This result indicated that partial -to under-recessiveness effects contributed in the inheritance of these two characters.

Positive and desirable heterotic effects for the characters number of branches per plant, plant height to the first flower, number of flowers per cluster and total soluble solids were also reflected by most of the $F_{1}$ hybrid generations, relative to their mid parents. The estimated values of potence ratios supported also these results, since they indicated that various degrees of partial - to over - dominance were involved in the inheritance of these characters, as appears in Tables 3 and 4.Similar results were obtained by Kurian and Peter (2001), and Hannan et al., (2007b)for total soluble solids; Haydar et al., (2007)for plant height at flowering; Hannan et al., (2007a) for number of flowers per cluster; who detected high heterotic responses on most hybrids, which supported the role of non-additive gene effects on the inheritance of these characters.

Concerning the number of fruits and total fruits weight per plant characters, the results indicated generally that desirable and positive heterotic effects were reflected on all evaluated $F_{1}$ hybrids. These results suggested clearly the important roles for the partialcomplete- and over-dominance on the inheritance of these two characters, as reflected on potence ratio estimates (Table 4). These results are in agreement generally with those obtained by several investigators such as Srivastava et al., (1998), Paradheep et al.,
(2006) and Hannan et al., (2007a); who found that most of their tested $\mathrm{F}_{1}$ hybrids exhibited positive heterosis. In this respect, Khalf-Allah(1971) found a high heterosis effect for total fruits yield which were reported to be around $200 \%$.

\section{General and Specific Combining Ability (G.C.A. and S.C.A.) Estimates.}

The results concerning the analyses of variance of combining ability effects on the various studied characters of the five parental cultivars and their all possible hybrid combinations (in one direction) are presented in Table 5. The results, generally, illustrated that the estimated variances for the effects of both general and specific combining abilities $\left(\sigma_{\text {gca }}^{2}\right.$ and $\left.\sigma_{\text {sca }}^{2}\right)$ showed relatively high values for all the studied characters. This result suggested that both additive and non-additive gene effects were important in controlling the expression of all studied characters. Also, the results illustrated generally that the comparison between the genetic variance components showed higher values of $\sigma^{2}{ }_{\text {sca }}$ than those of $\sigma^{2}{ }_{\text {gca }}$ for all the studied characters, with only three exceptions, suggesting that the nonadditive gene effects appeared to have, relatively, more important roles in the basic genetic mechanism, controlling the inheritance of these characters, relative to the additive gene effects. In this concern, Omara et al (1988)found that additive variance was consistently greater than that of the non-additive, indicating that the major portion of the genetic variation for the characters number of fruits per plant ,fruit weight and total yield per plant was controlled by genes with additive effects. Meanwhile, the non- additive gene effects were reported to form the main part of total genetic variation in total yield per plant as reported by Khalf - Allah and Mousa (1972) and Khalf - Allah and Kassem (1985).

The comparisons among the effects of the general combining ability(G.C.A) for the parental cultivars, and specific combining ability (S.C.A) for the $F_{1}$ hybrids, are presented in Tables 6 and 7, respectively.

The estimated values of the general combining ability (G.C.A.) effects of the parental cultivars, in Table 6 ,reflected that the best general combiner parent that appeared to have the significant highest positive value of G.C.A. was found to be cultivar "Super Marmand" for the characters plant height ,number of branches per plant and total soluble solids.The parental cultivar "Peto-86" was found to be a good general combiner for the characters plant height to the first flower, number of flowers per cluster , number of fruits per plant and fruit shape index. The results in Table 6 illustrated also that the parental cultivar "Edkawy" appeared to be good combiner parental cultivar for the 
characters fruit weight ,fruit diameter ,fruit length and fruit locules number. 



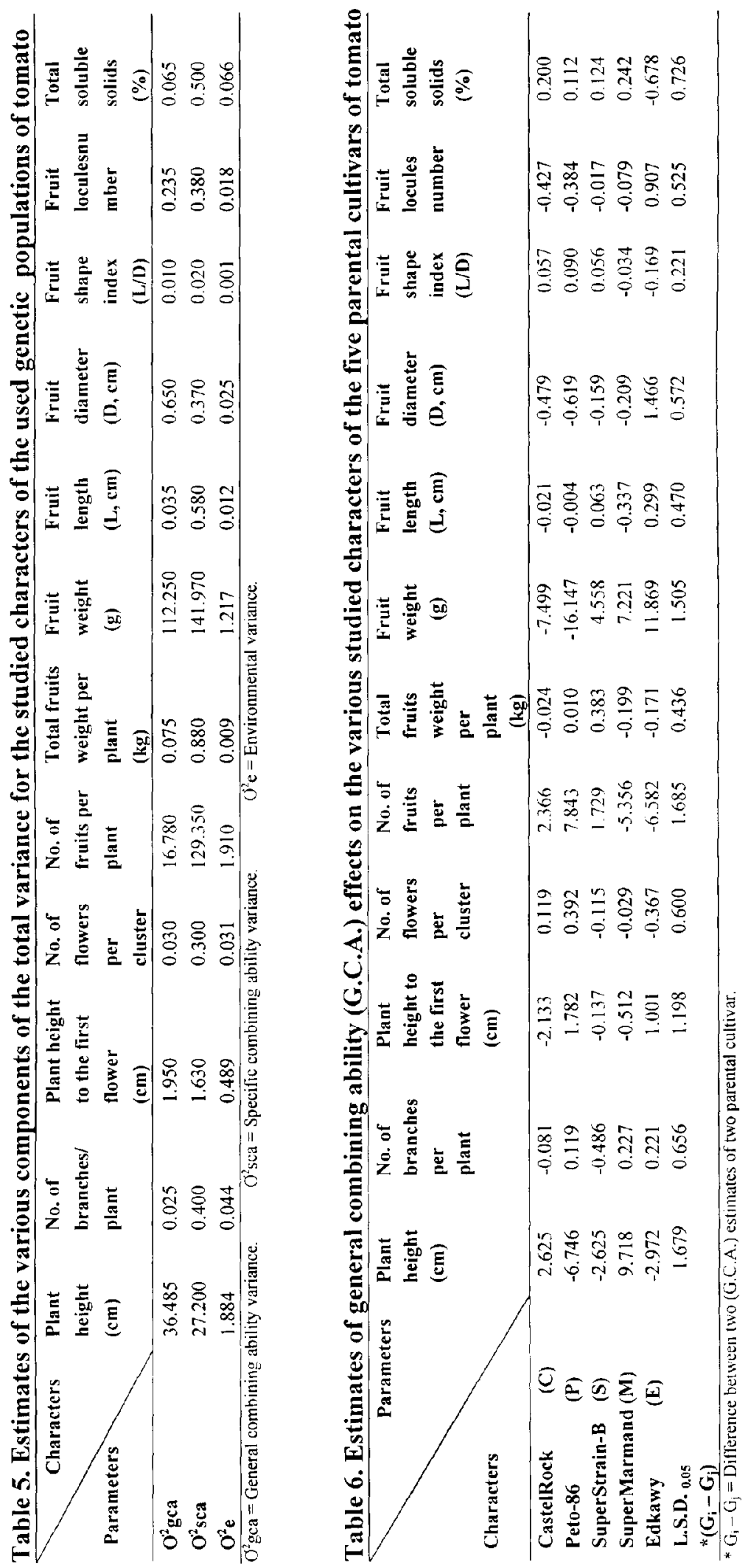


The best general combiner parent, which appeared to have the highest positive value of G.C.A. for the character total fruits weight per plant was the parental cultivar "Super Strain-B". From such results, it could be generally concluded that combining ability estimates can be used to select the parents to be involved in hybrid combinations to predict the best hybrids. However, it showed be mentioned that the parents with good G.C.A. do not necessarily produce superior cross with good S.C.A. in all combinations.

The comparisons among the estimated values of specific combining ability S.C.A., in Table 7, illustrated generally that five or more out of the ten $F_{1}$ hybrids reflected positive S.C.A. values for the characters fruit weight, fruit locules number, total fruits weight per plant ,total soluble solids ,number of flowers per cluster ,number of branches per plant, plant height to the first flower, and number of fruits per plant .Also, the results showed that from two to four $F_{1}$ hybrids reflected positive S.C.A. values for the characters fruit length ,fruit diameter, fruit shape index and plant height. Such results illustrated generally that both G.C.A. and S.C.A. effects were shown to be major contributing factors in tomato ,indicating the importance of additive and nonadditive types of gene action in the inheritance of the studied characters, but, with more pronounced effects of non-additive gene effects relative to the additive in most characters. This conclusion was in harmony with the findings of several investigators such as Khalf Allah and Kassem (1985) for fruit weight and total yield; Younis et al., (1989)for fruit shape index; Hazar et al., (2001) for fruit polar diameter , fruit equatorial diameter ,shape index,T.S.S., and number of locules per fruit; Pradheep et al.,(2006)for fruit weight and total yield per plant; Hannan et al., (2007b) for total soluble solids number of fruits per plant, fruit weight per plant ,number of flowers per cluster and total fruits yield per plant.; and Haydar et al., (2007) for plant height at flowering. They reported generally that both G.C.A. and S.C.A. effects were found to be high, but those of S.C.A. were more pronounced . However, Abd-Allah (1999), and Gad El- Hak et al., (1996) for fruit weight, total yield per plant and T.S.S.; and Younis et al., (1988) for number of locules per fruit found that G.C.A. effects were much greater in magnitudes than that of the S.C.A. effects. Their results indicated that the major portion of the genetic variation for these traits was controlled by genes with additive effects.

The results of the comparisons among the estimated values of specific combining ability S.C.A. illustrated that the best hybrid combination which showed the highest value for the plant height character was found to be the cross $\mathrm{C} \times \mathrm{M}$, indicating that parents $\mathrm{C}$ and $\mathrm{M}$ can combine well to produce a hybrid with a high general performance for this character. In this respect, it is noteworthy that not only the high performances of the parents involved in a cross were important in determining the general performance of the progeny, but also the S.C.A. effects involved.

The results illustrated that the cross $\mathrm{S} x \mathrm{E}$ could be considered as the best hybrid combination for the four characters number of branches per plant, plant height to the first flower ,number of fruits per plant and total fruits weight per plant, since, it showed the highest positive values for the S.C.A. effects. As for the characters fruit shape index and number of flowers per cluster, the best hybrid combination appeared to be $\mathrm{C} \mathrm{x}$ $\mathrm{P}$, suggesting that these two parental cultivars could combine well to produce high values of fruit shape index and more flowers per cluster. In the case of the character fruit weight, the $\mathrm{F}_{1}$ hybrid $\mathrm{M} \times \mathrm{E}$ gave the best combination, since the two parents combined well to produce the heaviest fruit weight .In this concern, the parents $\mathrm{M}$ and $\mathrm{E}$ gave the highest positive G.C.A. values, which means that the two parents were the good combiners for this character .

Pertaining the fruit length character, the presented results in Table 7 illustrated that the best combination was given by the cross $\mathrm{S} \times \mathrm{M}$, which showed the highest positive S.C.A. value, indicating that the two involved parents in this cross possessed good genes in general and reacted well to produce a hybrid with a high length of fruit. With respect to the fruit diameter and number of locules per fruit characters, the best hybrid combination was found to be the cross $\mathrm{P} \times \mathrm{S}$, which gave the highest positive value for S.C.A. effects, indicating that the two parents $\mathrm{P}$ and $\mathrm{S}$ can combine well to produce a hybrid with more locules number per fruit and a wider fruit. The results revealed also that the crosses $\mathrm{P}$ x M reflected higher positive values of S.C.A. for total soluble solids. This result illustrated that this $F_{1}$ hybrid could be considered as the best hybrid combination for total soluble solids.

\section{Estimates of the Heritability Percentages in Broad and Narrow Senses for the Various Studied Characters}

The results presented in Table 8 illustrated generally that the estimations of heritability percentages in the broad sense $\left(\mathrm{H}_{\text {b.s }}^{2} \%\right)$, for the various studied characters, were found to be high and ranged from $90.26 \%$ for total soluble solids characters up to 99.67 $\%$ for fruit weight character. This result seemed to agree with those obtained by Pradeepkumar et al., (2001), who found that all the studied characters had high heritability estimates in broad sense; i.e. $95.64 \%$ for plant height , $77.50 \%$ for number of fruits per plant, 
$92.76 \%$ for locules number per fruit, $90.90 \%$ for total soluble solids,

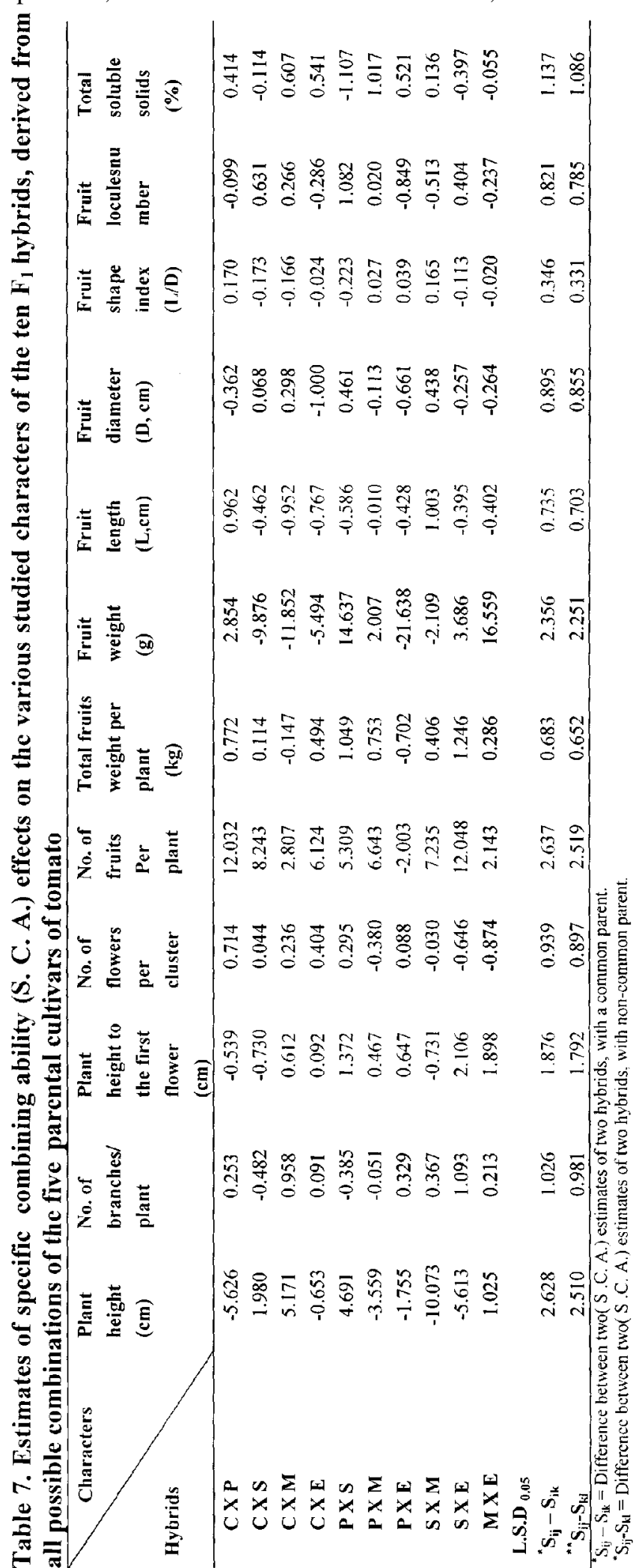


Solieman, T.H.I.: Diallel Analysis of Five Tomato Cultivars and Estimation of Some Genetic Parameters for Growth and Yield Characters 285

Table 8. Estimates of variance components and heritability in broad and narrow senses for the studied characters of tomato

\begin{tabular}{lcc}
\hline Characters & $\mathbf{H}_{\mathbf{b . s}}^{\mathbf{2}} \mathbf{( \% )}$ & $\mathbf{h}_{\mathbf{n} . \mathbf{s}}^{\mathbf{2}}(\boldsymbol{\%})$ \\
\hline Plant height $(\mathrm{cm})$ & 98.15 & 71.50 \\
No. of branches per plant & 91.09 & 10.12 \\
Plant height to the first flower (cm) & 91.87 & 64.79 \\
No. of flowers per cluster & 92.07 & 15.34 \\
No. of fruits per plant & 98.46 & 20.36 \\
Total fruits weight per plant (kg) & 99.13 & 14.44 \\
Fruit weight (g) & 99.67 & 61.06 \\
Fruit length (L, cm) & 98.19 & 10.57 \\
Fruit diameter (D, cm) & 98.52 & 76.70 \\
Fruit shape index (L/D) & 97.56 & 48.78 \\
Fruit locules number & 97.93 & 54.15 \\
Total soluble solids (\%) & 90.26 & 18.62 \\
\hline
\end{tabular}

$\mathrm{H}_{\mathrm{b} . \mathrm{s}}^{2}(\%)=$ Heritability percentage in broad sense.

$\mathrm{h}^{2}{ }_{\text {n.s }}(\%)=$ Heritability percentage in narrow sense.

$88.32 \%$ for fruit weight, and $60.54 \%$ for fruits yield per plant; indicating low influences of environment on them. Similar findings were reported by Prasad and Rai (1999)

The narrow sense heritability estimates, listed in Table 8, showed relatively high, intermediate or relatively low percentages. In the case of the four characters fruit weight, plant height to the first flower, plant height and fruit diameter; the estimated values of $\mathrm{h}^{2}$ n.s were found to be relatively high; since, the estimated percentages of the narrow sense heritability were found to be $61.06 \%, 64.79 \%, 71.50 \%$ and $76.70 \%$, respectively. Such results suggested that ,though both additive and non- additive gene effects were involved in the inheritance of these four characters, the nonadditive gene effects contributed relatively higher portions for its genetic variances.

The results of the estimated values of narrow sense heritability showed intermediate percentages for the two characters fruit shape index and number of locules per fruit, which gave the values $48.78 \%$ and $54.15 \%$ ,respectively .This result indicated that both additive and non-additive gene effects played an important role in the inheritance of these characters. The next characters in this respect appeared to be number of fruits per plant ,total soluble solids, number of flowers per plant ,total fruits weight per plant ,fruit length and number of branches per plant, which gave relatively low percentages;i.e., $20.36 \%, 18.62 \%, 15.34 \%, 14.44 \%$ , $10.57 \%$ and $10.12 \%$, respectively. These results indicated that both additive and non-additive gene effects appeared to be very important, but with some relative advantage for non -additive gene effects ,to the inheritance of these characters. However, Omara et al.,

(1988) found that heritability estimates in narrow sense were high for number of fruits per plant (93.\%), and moderate for total fruits weight per plant (58\%).

\section{REFERENCES}

Abd-Allah, E.M.M.1999. Combining ability, heterosis and correlation studies for some quantitative characters of tomato in the late summer planting. Zagazig J. Agric. Res. 26(3A):623-636.

Abdel-Ati, K. E. A. 1999. Evaluation of some tomato cultivars and their $F_{1}$ hybrids for some economic characters using diallel analysis. Egypt J. Plant Breed. 3:313- 328 .

Ahmed, S. U.; K. Sahs and K. F. Sharfdin. 1988. Study of heterosis and correlation in tomato. Thai. J. Agric. Sci. 21(2):117-123.

Ajeet, S.; P. K. Singh and J. Dixit. 1996 . Heterosis and inbreeding depression in tomato. J. Res. Birsa Agric. Univ. 8(1):8990.

Al-Rawi,K.M. and A.M. Khalf-Allah.1980.Design and analysis of agricultural experiments.Text book.El-Mousl Univ.Press.Ninawa, Iraq.pp.487(In Arabic).

Bai, Y. and P. Lindhout.2007. Domestication and breeding of tomatoes: what have we gained and what can we gain in future?. Annals of Botany. 100(5):10851094.

Cockerham,C.C.1961.Implication of genetic variances in hybrid breeding program.Crop Sci. 1:47-52.

Co-State Software.2004.User's manual version.Cohort Tusson,Arizona,USA.

GadEl-Hak,S.H.;A.Z.Mohamed;S.H.Mohamed;Y.Y.Abd ElAti and E.M.Abd Allah .1996.Estimates of hybrid vigor and combining ability in tomato.Proceeding of Fourth Arabic Conference for Horticultural Crops. ElMinia,Egypt.March.189-213. 
Geleta,F.,L.Labuschagne and T.Maryke.2006. Combining ability and heritability for vitamin $\mathrm{C}$ and total soluble solids in peper (Capsicum annum,L).J.Sci.Food and Agric.86(9):1317-1320.

Ghosh, P. K.; M. M. Syamal and A. K. Joshi. 1996.Graphical analysis of gene effects in tomato (Lycopersicon esculentum, Mill). Adv.Pl. Sci. (1):55-59.

Gibrel, G. A. A.; W. R. Simpson and D. O. Everson. 1982. Evaluation of $F_{1}$ hybrid tomato cultivars for earliness, fruit size and yield using diallel analysis. J. Amer.Soc. Hort. Sci. 107(2):243-247.

Griffing, B. 1956a. Concept of general and specific combining ability in relation to diallel systems. Aust. J. Biol. Sci. 9:463-493.

Griffing,B.1956b.A general treatment of the use of diallel crosses in quantitative inheritance.J.Heredity 10:31-50.

Hannan, M.M.; M.B. Ahmed; U.K.Roy; M.A. Razvy;A. Haydar; M.A.Rahman;M.A.Islam and R. Islam. 2007a. Heterosis, combining ability and genetics for brix \%, days to first fruit ripening and yield in tomato (Lycopersicon esculentum, Mill). Mid.East J. Sci. Res. 2(3-4): 128-131.

Hannan, M.M.; M.K. Biswas; M.B. Ahmed; M. Hossain and R. Islam.2007b .Combining analysis of yield and yield components in tomato (Lycopersicum esculer2tumy, Mill). Turk. J. Bot. 31:559-563.

Hanson, P.M.;J.T Chen and G. Kuo. 2002. Gene action and heritability of high temperature of high- temperature fruit set in tomato line CL5915. Hort Sci. 37(1):172-175.

Haydar, A.;M.A. Mondal; M.B. Ahmed; M.M. Hannan;R. Karim;M.A. Razvy; U.K. Roy and M. Salahin.2007. Studied on Variability and interrelationship among the different traits in tomato (Lycopersicon esculentum, Mill). Mid.-East J. Sci. Res.2(3-4):139-142.

Hazar, P.; R.K. Das; M.K. Pandit and P.K. Sahu. 2001. Genetical studies on flower and fruit characters in an inter-specific cross of tomato. Indian J. Gene. Pl. Breed. 61(2):143-146.

Khalf-Allah,A.M.1971.Studies of general and specific combining ability of quantitative characters in tomato.Alex.J.Agric.Res.18:207-212.

Khalf-Allah,A.M. and A.G.Mousa.1972.Relative importance of types of gene action for early yield, total yield and fruit size in tomato.Egypt.J.Genet.Cytol.1:51-60..

Khalf-Allah,A.M.and E.Kassem.1985. A diallel analysis of quantitative characters tomato. Egypt.J.Genet Cytol.14:251-257.

Khalil, R. M.; A. A. Midan and A. K. Hatem. 1988. Breeding studies of some characters in (Lycopersicon esculentum, Mill). Acta Hort. 220:77-83.

Kurian, A. A. and K. V. Peter. 1997. Association on fruit shape index and quality characters in tomato. Indian $\mathrm{J}$. Genet.Pl. Breed. 57(1):82-86.
Kurian, A. and K.V. Peter. 2001. Heterosis for quality traits in tomato. J. Trop. Agric. 39:13-16.

Kurian, A.; K.V. Peter and S. Rajan. 2001.Heterosis for yield components and fruit characters in tomato. J. Trop. Agric. 39:5-8.

Mather,K. and J.L.Jinks.1971. Biometrical genetics. $2^{\text {nd }}$ ed.Chapman and Hall Ltd. London.U.K.

Omara, M. K.; S. E. A. Younis and H. I. Tahany. 1988. A genetic analysis of yield and yield components in tomato. Assiut J. Agric. Sci. 19(1):227-240.

Pradeepkumar, T.; D.B. Joy; N.V. Radhakrishnan and K.C. Aipe. 2001. Genetic variation in for yield and resistance to bacterial wilt. J. Trop. Agric. 39:157-158.

Pradheep, K.;D.V. Thatham and J. Auxcilia. 2006. Heterosis and combining ability studies in tomato (Lycopersicon esculentum, Mill) with an emphasis to virus resistance. Madras Agric. J.93(7- 12):239-247.

Prasad,V.S. and R.K Rai .1999.Genetic variation component association and direct and indirect selection in some exotic tomato germplasn.Indian J.Hort.56:262-266.

Pratta, G. R. and L. A Picardi. 2003. Diallel analysis of production traits among domestic, exotic and mutant germplasms of Lycopersicon. Genet. Mol. Res. 2(2):206213.

Semel, Y.; J. Nissenbaum; N. Menda; M. Zinder; U. Krieger; N. Issman; T.Z. Lippman; A. Gur and D. Zamir.2006. Over-dominatant quantitative trait loci for yield and fitness in tomato.Agric.Sci 103(35):12981-12986.

Singh, H. and D.S. Cheema. 2005. Studies on genetic variability and heritability for quality traits of (Lycopersicon escuelntum, Mill) under heat stress conditions. J. Appl. Hortic. 7(1):55-57.

Singh, P. K.; R. K. Singh and B. C. Saha, 1988. Genetic variability in tomato (Lycopersicon esculentum). Indian J. Agric. Sci. 58(9):718-720.

Smith,H.H.1952.Fixing transgressive vigour in nicotiana rustica .In heterosis ,Iowa State Press,Ames,Iowa ,U.S.A.

Srivastava, J.P.;B.P. Srivastava; H.P. Verma and H. Singh. 1998. Heterosis in relation to combining ability in tomato. Veget. Sci.J. 25(1):43-47.

Suresh, K.; M. K. Banerjee and P. S. Partap. 1995. Studies on heterosis for various characters in tomato. Haryana $\mathrm{J}$. Hort. Sci. 24(1):54-60

Wahb-Allah,M.A.E.2000.Estimation and efficiency of parameters contributing to genetic variance, Combining ability and heritability of growth and yield characters of tomato. Ph.D Thesis, Vegetable Crops Dept. Alexandria Univ. Egypt.

Younis, S.E.A.;M.K. Omara and M.Y. Hussein. 1988. A genetic analysis of fruit characteristics and their interrelationships in the tomato (Lycopersicon esculentum, Mill). Assuit J. Agric. Sci.19(3):312-324. 


\section{الملخص العربي}

\section{تحليل الداى أليل لحمسسه أصناف من الطماطم وتقدير بعض المقاييس الوراثية الهامة لبعض صفات النمو و الخصصول و مكوناته}

طلعت حسن إبراهيم سليمان

الثمرة ونسبة المواد الصلبة الذائبة الكلية والوزن، عدد الحجرات في الثمرة.) كما تم تسجيل العدد الكلى للثمار وذلك المحصول الكلى لكل نبات. ثم أجريت التحليلات الإحصائية علي البيانات المدروسة لتقدير المقاييس الوراثية اللازمة في الدراسة. أوضحت نتائج تقدير أنواع التفاعل الجيني وتقـــــير الأهميـــة

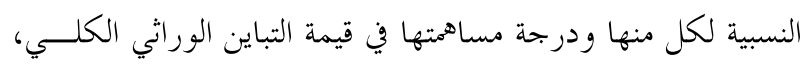
ان كل من التأثيرات المضيفة والتأثيرات الغير مضيفة قد اشتركت في

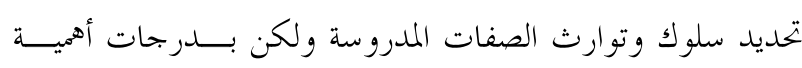

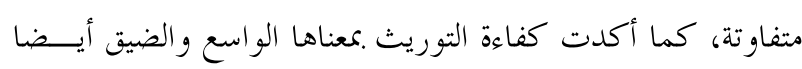

النتيجة السابقة. بالنسبة للسلوك العام للعشائر الو راثية، فقد أوضحت النتائج أن القيم العالية في صفات ارتفاع النبات، ارتفاع النبات حستى أول زهرة، قطر الثمرة قد تأثرت بوضوح بالتأثيرات الإضافية والسيادية (بدرجات سيادة متفاوتة)، وذلك بالمقارنة بالصورة المقابلة وهـــي القيم المنخفضة لهذه الصفات، مبينة أن التأثير الإضافي قد أظهر أهمية

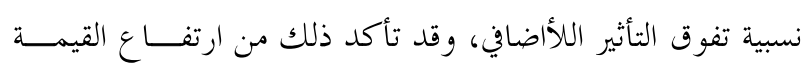
المقدرة لتباين القدرة العامة علي التآلف عن قيمة تبـــاين القـــــرة

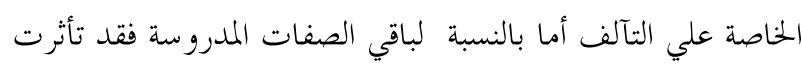

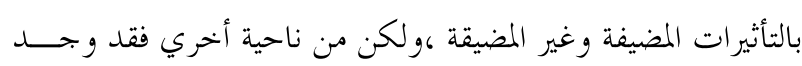

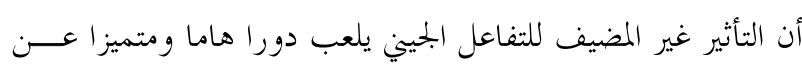

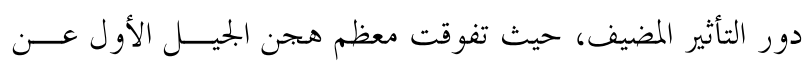

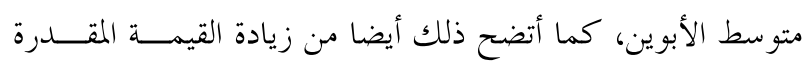

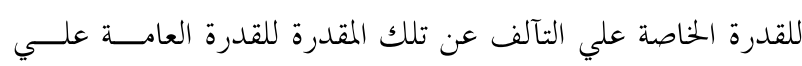
التآلف.

أظهرت النتائج أيضا أن قيم صفات المحصول و مكوناته لمعظم عشائر الهجن قد أعطت متوسطات اما اعلي من متوسط الأبوين أو
أجريت هذه الدراسة خلال ثلاث مواسم زراعية في الأعــــوام

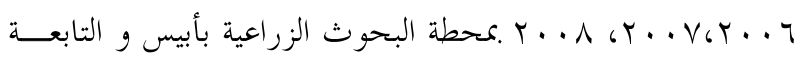
لكلية الزراعة-جامعة الإسكندرية. وذلك همف تقييم السلوك العام للتراكيب الوراثية لخمسة أصناف من الطماطم وكل الهجن الممكنة

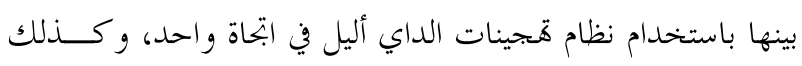

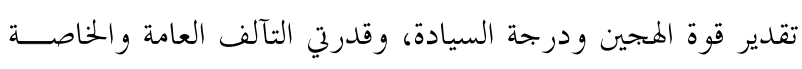

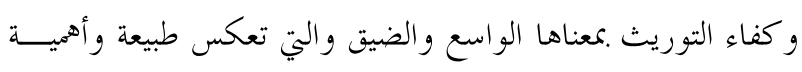
أنواع التفاعل الجيني المتحكم في السلوك الوراثى لبعض الــصفات الهامة في الطماطم.

تمت زراعة البذور وأجري التلقيح الذاتي لخمسة أصناف مــن الطماطم وهي (كاسل روك، بيتو -1 ب، سوبر سترين-بى، ســـوبر

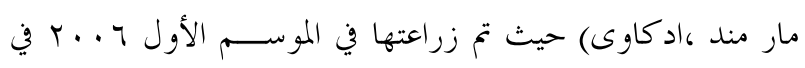

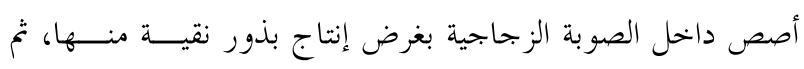

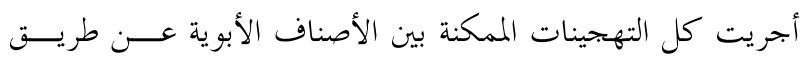

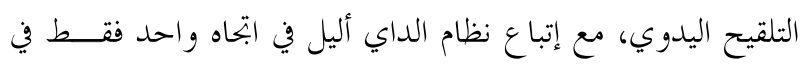

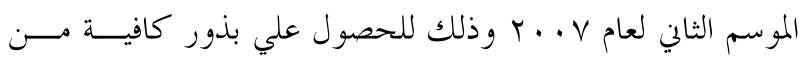

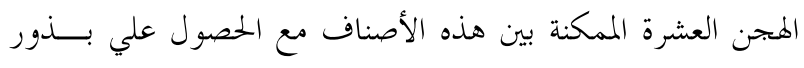
جديدة للخمسة آباء بترك بعض النباتات للتلقيح الذاتي. في الموسم الثالث م · . ب، زرعت بذور كل العشائر الو راثية المختلفة الآبــاء والهجن(0 اعشيرة) في تجربة تقييم باستخدام تصميم القطاعــات العشوائية الكاملة بثلاث مكررات.

عند بداية العقد تم أخذ بعض القياسات الخضرية علي كـلـ

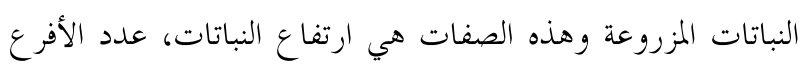

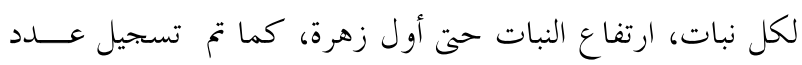

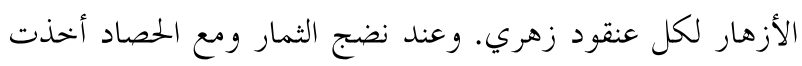
خمس ثمار كعينة ممثلة من كل نبات علي حده في طور النضج الأحمر عشوائيا، وذلك لتقدير قياسات الثمار (وهي طول، قطر وشكل 
الثمرة. كما تميز الصنف ادكاوى بقدرة ائتلاف عامة عالية لصفات وزن الثمرة، قطر الثمرة، طول الثمرة، عدد الحجرات في الثمرة، أما الصنف سوبر سترين -بى فقد تميز بقدرة ائتلاف عامة عالية وموجبة

$$
\text { لصفة المصول الكلى للثمار. }
$$

أظهرت النتائج أيضا ان أفضل توليفة للهجن والتي تعكــس أعلى قيمة موجبة للقدرة الخاصة على التالف كانت للجيل الهجينى

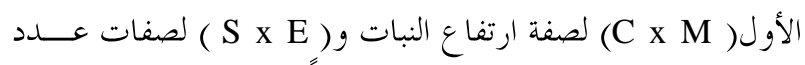
الأفرع لكل نبات، ارتفاع النبات حتي أول زهرة، وعدد الثمار لكل

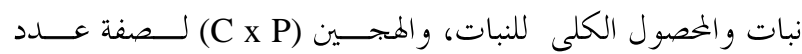
الأزهار لكل عنقود زهري، و الهجين (S x M) لصفة طول الثمرة،

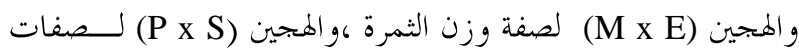
قطر الثمرة وعدد الحجرات لكل ثمرة، والهجين( C x P) لصفة دليل شكل الثمرة، والهجين(P x M لصفة محتوى الثمرة مـــن المـــواد

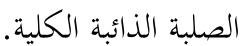

قريبة من قيم الآباء الأعلى. أما بالنسبة لتقديرات قوة الهجين، فقـــــ أبرزت النتائج وجود تأثيرات موجبة مرغوبة فى رفع قـيم معظــم الصفات المدروسة لمعظم الهجن وذلك على أساس متوسط الأبـــوين ،مع وجود بعض الاستثناءات كنتيجة لاعطاء قيم ســالبة اوغــير

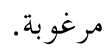
وقد أبرزت نتائج القدرة العامة والخاصة علي التآلف عـــدم إمكانية الاعتماد علي صنف واحد من الأصناف الأبوية المختبرة أو علي هجين واحد لتقييم جميع الصفات المدروسة بــنفس درجـــة

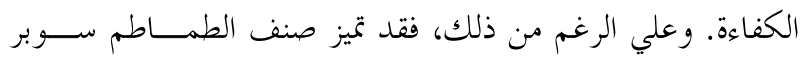
مارمند بقدرة تالف عامة عالية في ابتحاه القيم الموجبة في كـلـل مــن الصفات ارتفاع النبات، عدد الأفرع لكل نبات ومحتوى الثمار من المواد الصلبة الذائبة الكلية، واظهر الصنف بيتو-1م قدرة ائستلاف عامة موجبة وعالية لصفات ارتفاع النبات حتى أول زهرة، عـــدد الأزهار لكل عنقود زهري ،عدد الثمار لكل نبات، ودليل شكل 